\title{
Activation of Antigen-specific Suppressor T Cells in the Presence of Cyclosporin Requires Interactions
} between $\mathrm{T}$ Cells of Inducer and Suppressor Lineage

\author{
Nahid Mohagheghpour, Claudia J. Benike, Geoffrey Kansas, Charles Bieber, \\ and Edgar G. Engleman, Department of Pathology, Stanford University \\ School of Medicine, Stanford, California 94305
}

\begin{abstract}
A в S T R A C T To probe the mechanism of suppressor $T$ cell generation in man, we have carried out mixed leukocyte reactions (MLR) in the presence of cyclosporin (CsA), a fungal metabolite which prevents the generation of cytotoxic lymphocytes while permitting activation of suppressor cells. After a 12-d MLR in the presence of $1 \mu \mathrm{g} / \mathrm{ml} \mathrm{CsA}$, T cells were fractionated into subsets with monoclonal antibodies, and each subset was tested for the ability to inhibit a second fresh MLR that is devoid of CsA. The results show that Leu $2^{+} \mathrm{T}$ cells derived from the first culture suppress the second MLR in an HLA-DR antigen-specific manner and in the absence of detectable lysis of stimulator cells. However, Leu $2^{+}$cells do not develop into suppressor cells unless acted upon by alloantigen-primed Leu $3^{+}$inducer cells. Furthermore, only those Leu $3^{+}$cells that also express the Leu 8 marker $\left(\right.$ Leu $3^{+}, 8^{+}$) are capable of inducing suppressor cells. Thus, antigen-specific feedback inhibition of an immune response in man results from an ordered series of interactions between $T$ cells of distinct phenotype.
\end{abstract}

\section{INTRODUCTION}

Both alloantigen-specific cytotoxic $(\mathrm{Tc})^{1}$ and suppressor (Ts) $\mathrm{T}$ cells are generated in the mixed leukocyte reaction (MLR) (1-3). However, because Tc and Ts cannot be distinguished from one another with available antibodies to $T$ cell surface markers (4-8), the possibility remains that apparent suppression is, in fact, due to lysis of allogeneic stimulator cells. Recently, activation of $\mathrm{Ts}$ in the absence of $\mathrm{T} c$ has been achieved by carrying

\footnotetext{
Received for publication 14 March 1983 and in revised form 8 July 1983.

${ }_{1}^{1}$ Abbreviations used in this paper: $\mathrm{CM}$, completed medium; CsA, cyclosporin; MLR, mixed leukocyte reaction; Tc, cytotoxic $\mathrm{T}$ cells; Ts, suppressor $\mathrm{T}$ cells.
}

out MLR in the presence of cyclosporin (CsA) (9), a fungal metabolite which has been used clinically to prevent rejection of organ allografts (10-12). We have used CsA and previously defined anti-T cell monoclonal antibodies (7, 13-14) to characterize MLR-generated Ts and to probe the mechanism of their activation. Our results show that Ts inhibit fresh MLR in an HLA-DR antigen-specific manner without detectable lysis of stimulator cells. The activation of these suppressor cells is dependent on ordered interactions between $T$ subsets of distinct lineage.

\section{METHODS}

Monoclonal antibodies. Monoclonal anti-Leu 2a and antiLeu 3a define antigens expressed on mutually exclusive subpopulations of peripheral $T$ cells that mediate predominantly suppressor/cytotoxic and helper/inducer functions, respectively $(7,8,13)$. Anti-Leu 8 defines an antigen that is present on $50-65 \%$ of Leu $2^{+}$cells and $75-90 \%$ of Leu $3^{+}$T cells (14). All three antibodies were generously provided by $\mathrm{Dr}$. R. L. Evans, Memorial Sloan-Kettering Cancer Center, New York.

Preparation of $T$ and non-T cells. Peripheral blood mononuclear leukocytes (PBML) were isolated from healthy volunteers by Ficoll-Hypaque gradient centrifugation of fresh defibrinated blood (15). T and non-T cells were separated from PBML with a sheep erythrocyte-rosetting technique (16) by using sheep erythrocytes that were treated with 2aminoethylisothiouronium bromide hydrobromide (Sigma Chemical Co., St. Louis, MO). Rosetted (T) and nonrosetted (non-T) fractions contained $90-95$ and $1-5 \% \mathrm{~T}$ cells, respectively, based on staining with a fluoresceinated pan-T monoclonal antibody, anti-Leu 1 (17) (Becton-Dickinson Corp., Orangeburg, NY).

Fresh or cultured T cells were separated into Leu $2^{+} /$Leu $2^{-}$, Leu $3^{+} /$Leu $3^{-}$, or Leu $8^{+} /$Leu $8^{-}$subpopulations by using monoclonal antibodies and a "panning" technique (8, 14). Based on cytofluorographic analysis (Ortho System $50 \mathrm{H}$; Ortho Pharmaceutical Corp., Raritan, NJ), at least $97 \%$ of positively selected populations expressed the antigen for which they were selected, whereas the negatively selected fractions contained $<5 \%$ contaminating cells. 
Cell cultures. Ts were generated in $25 \mathrm{~cm}^{2}$-flasks that contained $10^{7}$ responder $\mathrm{T}$ cells and an equal number of irradiated $\left(2,000\right.$ rads from a ${ }^{137}$ Cesium irradiator, J. L. Shepherd \& Associates, Glendale, CA) allogeneic non-T cells or Ebstein-Barr virus-transformed $B$ cell lines $(6,000 \mathrm{rad})$ in a final volume of $21 \mathrm{ml}$ of completed medium (CM). CM consisted of RPMI 1640 supplemented with $25 \mathrm{mM}$ Hepes buffer, $2 \mathrm{mM}$ L-glutamine, $100 \mathrm{U} / \mathrm{ml}$ penicillin, $100 \mu \mathrm{g} / \mathrm{ml}$ streptomycin, and $20 \%$ heat-inactivated pooled human serum. Replicate cultures were maintained in the presence of $1 \mu \mathrm{g} /$ ml CsA (Sandoz Ltd., Basel, Switzerland) for $12 \mathrm{~d}$ at $37^{\circ} \mathrm{C}$ in a humidified atmosphere of $10 \% \mathrm{CO}_{2}$ in air. Thereafter, the activated $\mathrm{T}$ cells were incubated in fresh $\mathrm{CM}$ for $1 \mathrm{~h}$ at $37^{\circ} \mathrm{C}$ and washed three times to remove CsA before being tested for their suppressive effect on fresh MLR.

Suppressor assays consisted of $10^{5}$ fresh T cells autologous to the putative suppressors, $10^{5}$ irradiated $(3,000 \mathrm{rad})$ allogeneic non-T cells, and the indicated numbers of irradiated $(1,500 \mathrm{rad}) \mathrm{T}$ cells from CsA-treated MLR. Cultures were maintained in $0.15 \mathrm{ml}$ of $\mathrm{CM}$ in 96 well, round-bottomed microtiter plates (Flow Laboratories, Inc., McLean, VA) for $6 \mathrm{~d}$. To measure $\mathrm{T}$ cell proliferation, cultures were pulsed with $1 \mu \mathrm{Ci} /$ well $\left[{ }^{3} \mathrm{H}\right]$ thymidine (New England Nuclear, Boston, MA; $6.7 \mathrm{Ci} / \mathrm{mM}$ ) and harvested $18 \mathrm{~h}$ later. Assays were performed in sextuplicate and the incorporated radiolabel was measured in a liquid scintillation spectrometer. The results are presented as mean counts per minute \pm SD. The percent suppression was calculated as follows: Percent suppression $=(1-[\operatorname{cpm}\{\mathrm{T}+$ non- $\mathrm{T}+\mathrm{Ts}\} / \operatorname{cpm}\{\mathrm{T}+$ non- $\mathrm{T}+\mathrm{T}$ control $\}]) \times 100$, where $\mathrm{Ts}$ is $\mathrm{T}$ cells that were activated in the presence of CsA and T control is $\mathrm{T}$ cells that were cultured in medium alone.

Cell-mediated lympholysis. Alloantigen-activated T cells harvested from CsA-treated or CsA-untreated MLR were used as effectors in a $4 \mathrm{~h}^{-51}$ chromium release assay (18). PBML from the responder as well as the stimulator which was cultured in CM for $7 \mathrm{~d}$ served as targets. Maximum and spontaneous ${ }^{51}$ chromium release values were obtained by adding $0.2 \mathrm{ml}$ of $\mathrm{H}_{2} \mathrm{O}$ or $\mathrm{CM}$, respectively, to microtiter wells containing $5 \times 10^{3}$ target cells. Effector to target ratios of 12 , 25,50 , and $75: 1$ were tested in quadruplicate.

\section{RESULTS}

Preliminary experiments (not shown) confirmed that $T$ cells derived from MLR which were carried out in

TABLE I

Cytotoxic Activity of CsA-treated Alloactivated T Cells Restimulated in the Absence of CsA

\begin{tabular}{lcccccc}
\hline & \multicolumn{5}{c}{ Days post secondary challenge } \\
\cline { 2 - 6 } \multicolumn{1}{c}{ Target cells } & 0 & 1 & 2 & 4 & 7 \\
\hline & \multicolumn{5}{c}{$\%$ lysis } \\
Autologous control & -0.8 & 0.8 & 0.4 & 0.9 & 4.6 \\
Allogeneic stimulator & 0.5 & 0 & 1.8 & 3.9 & 0.7 \\
\hline
\end{tabular}

Alloactivated T cells from primary 12-d MLR generated in the presence of CsA were tested for cytotoxic activity at the time of harvest and at $1,2,4$, and $7 \mathrm{~d}$ after allogeneic rechallenge in the absence of CsA. Data is shown for an effector:target ratio of 75:1. Control primary cultures devoid of CsA demonstrated $42.9 \%$ specific lysis against the original stimulator on day 0 of secondary challenge.

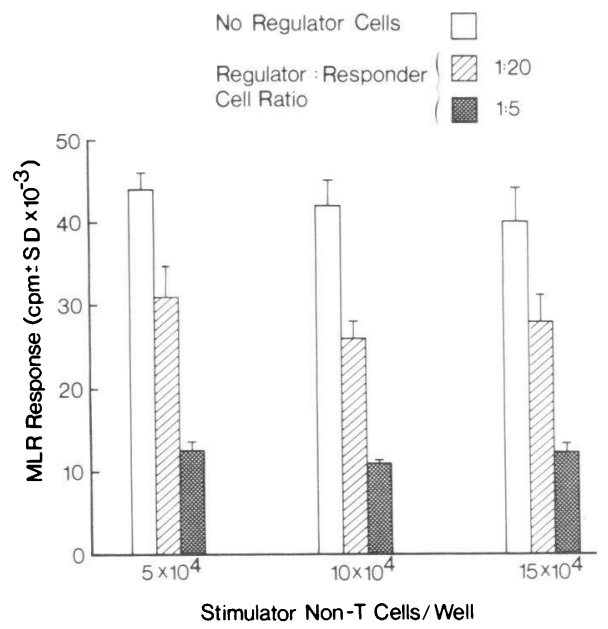

Figure 1 Suppression of MLR by $T$ cells primed in the presence of CsA: an increase in the number of stimulator cells in indicator MLR does not affect suppression. Suppressor assays consisted of $10^{5}$ fresh $\mathrm{T}$ cells, $5 \times 10^{4}$ to $15 \times 10^{4}$ irradiated $(3,000 \mathrm{rad})$ allogeneic non-T cells, and irradiated $(1,500 \mathrm{rad}) \mathrm{T}$ cells from CsA-treated MLR in numbers indicated. Proliferation was measured on day 6 and the results of sextuplicate cultures are presented as mean counts per minute \pm standard deviation.

the presence of $1 \mu \mathrm{g} / \mathrm{ml} \mathrm{CsA}$ were markedly suppressive of fresh MLR, but had no detectable cytotoxic activity against the priming cell. Moreover, irradiation of primed $T$ cells with $1,500 \mathrm{rad}$, a dose sufficient to prevent proliferation, did not interfere with their suppressive effect. Although these results confirm a previous report (9), we were concerned that suppression of fresh MLR by CsA-treated, alloantigen-activated $T$ cells might reflect their differentiation into Tc during the second culture and resultant lysis of allogeneic stimulator cells. To assess this possibility, MLR were established in the presence of CsA, and after $12 \mathrm{~d}$, the alloactivated $T$ cells were rechallenged with fresh stimulator cells in medium devoid of CsA. $4 \mathrm{~h}{ }^{51}$ chromium release assays, which were carried out at $1,2,4$, and $7 \mathrm{~d}$ after rechallenge, revealed no detectable lysis of priming cells at an effector to target ratio of $75: 1$, the highest ratio tested (Table I). Moreover, suppression of the MLR remained intact even if the number of stimulator cells was increased threefold (Fig. 1); this suggests that stimulator non- $\mathrm{T}$ cells are not the target of suppression.

We repeatedly observed that alloantigen-activated $T$ cells suppressed the proliferation of fresh autologous $T$ cells to the original but not third party stimulator cells. To explore the nature of this antigenic specificity, graded numbers of CsA-treated, MLR-derived T cells were tested for their ability to suppress the response of fresh autologous $T$ cells to stimulating non- $T$ cells 
with defined HLA-A, B, and DR allotypes. As shown in Table II, the responses to cells that shared at least one DR allele with the original stimulator were inhibited regardless of their HLA-A and B types. For example, in experiment 3 , Table II, $T$ cells activated with allogeneic Ebstein-Barr virus-transformed Arent cells (HLA-A2,2;B16,16;DR6,6) suppressed the response of fresh autologous $\mathrm{T}$ cells to the Arent line; to donor L.F.'s non-T lymphoid cells, which share DR but not $A$ or $B$ antigens with the original priming cell; and to the Daudi line, which expresses no HLA-A or B antigens but shares the DR6 allele with the Arent line. On the other hand, the response to E.E.'s cell (HLA$\mathrm{A} 2,24 ; \mathrm{B} 16,16 ; \mathrm{DR} 3,5)$, which shares HLA-A and B but

TABLE II

Antigen-specificity of Suppressor T Cells Derived from CsA-treated MLR

\begin{tabular}{|c|c|c|c|c|c|c|c|c|}
\hline \multirow[b]{2}{*}{ Responder } & \multirow[b]{2}{*}{ Stimulator } & \multicolumn{3}{|c|}{ HLA } & \multicolumn{4}{|c|}{ Suppressor:responder cell } \\
\hline & & A & B & DR & & & & \\
\hline & & & & & $c p m$ & $\% \operatorname{supp}$ & $c p m$ & $\%$ supp \\
\hline \multicolumn{9}{|c|}{ Experiment 1} \\
\hline \multirow[t]{7}{*}{$\mathrm{DN}$} & & 26,28 & 31,55 & 5,7 & & & & \\
\hline & $\mathrm{CW}^{\circ}$ & 11,29 & $44,-$ & 2,4 & 21,627 & $65 \dagger$ & 26,745 & $56 \dagger$ \\
\hline & CB & 1,2 & 7,27 & 2,4 & 31,976 & $59 \dagger$ & 39,687 & $41 \dagger$ \\
\hline & KJ & 3,3 & 7,7 & 2,2 & 52,015 & $34 \dagger$ & 58,364 & $26 \dagger$ \\
\hline & RJ & 2,2 & 44,44 & 4,4 & 14,630 & $42 \dagger$ & 27,780 & -10 \\
\hline & MC & 28,29 & $44,-$ & 4,4 & 12,741 & $34 \dagger$ & 20,389 & -6 \\
\hline & JC & 1,1 & 8,8 & 3,3 & 19,200 & -6 & 21,205 & -5 \\
\hline
\end{tabular}

Experiment 2

EE

$\begin{array}{lccccccr} & 2,24 & 16,16 & 3,5 & & & & \\ \text { JO } & 2,3 & 7,7 & 2,2 & 46,764 & 49 \dagger & 67,728 & 26 \dagger \\ \text { KJ } & 3,3 & 7,7 & 2,2 & 50,285 & 44 \dagger & 55,190 & 38 \dagger \\ \text { CW } & 11,29 & 44,- & 2,4 & 49,802 & 43 \dagger & 72,175 & 17 \\ \text { CB } & 1,2 & 7,27 & 2,4 & 31,072 & 52 \dagger & 57,348 & 12 \\ \text { PG } & 3,3 & 35,40 & 4,6 & 111,852 & 5 & 99,404 & 7 \\ \text { CT } & 2,28 & 8,44 & 4,- & 55,439 & 18 & 67,302 & 0 \\ \text { MS } & 1,2 & 17,17 & 7,7 & 30,854 & 18 & 33,270 & 12\end{array}$

Experiment 3

CW

$\begin{array}{lccc} & 11,29 & 44,- & 2, \\ \text { Arent }{ }^{\circ} \S & 2,2 & 16,16 & 6, \\ \text { Daudi } \S & - & - & 6, \\ \text { LF } & 23,31 & 18,60 & 4, \\ \text { EE } & 2,24 & 16,16 & 3, \\ \text { TC } & 3,- & 14,50 & 1,7 \\ \text { LBF } \$ & 30,30 & 13,13 & 7,7\end{array}$

2,4
6,6
6,6
4,6
3,5
1,7
7,7

65,576
60,816
34,030
61,230
44,026
68,230

$56 \dagger$
$55 \dagger$
$58 \dagger$
22
9
20

75,297

66,950

71,480

81,604

47,312

83,095

$49 \dagger$
$50 \dagger$
12
-2
3
3

Experiment 4

DN

$\begin{array}{lcr} & 26,28 & 31,55 \\ \text { MC } § & 28,29 & 44,- \\ \text { NM } & 30,32 & 13,61 \\ \text { ND } & 26,29 & 7,55 \\ \text { RA } & 2,24 & 37,61 \\ \text { WT49 } & 2,2 & 17,17\end{array}$

\begin{tabular}{lr}
5,7 & \\
4,4 & 17,545 \\
4,7 & 34,085 \\
9,10 & 68,750 \\
2,10 & 78,280 \\
3,3 & 112,460 \\
\hline
\end{tabular}

$\begin{array}{rr}84 \dagger & 82,505 \\ 32 \dagger & 43,015 \\ 14 & 69,569 \\ 16 & 106,047 \\ 2 & 140,378\end{array}$

$26 \dagger$
15
13
-13
-22

$5 \times 10^{3}$ or $2 \times 10^{4} \mathrm{~T}$ cells activated in CsA-treated MLR were tested for their ability to suppress the proliferative response of $10^{5}$ fresh autologous $\mathrm{T}$ cells to a panel of stimulating non-T cells. \% supp, percent suppression.

- Original stimulator.

† Suppression statistically significant $(P<0.01)$ by two-tailed $t$ test.

$\S$ Ebstein-Barr virus-transformed B cell lines. 
not DR with Arent, was unaffected. Moreover, inhibition was greatest when the stimulator cell shared both DR alleles with the priming cell; this possibly indicated the presence of suppressor $\mathrm{T}$ cells with specificity for either one or the other DR allele. These results suggest that HLA-DR antigens or products of loci linked to DR genes are the major stimuli for suppression. However, the observed antigen specificity rules out the possibility that suppression is due to CsA that is carried over into the indicator MLR.

To define the phenotype of Ts, primed T cells were fractionated into subsets with monoclonal antibodies and each subset was co-cultured with fresh autologous $T$ responder cells and non- $T$ stimulator cells from the original allogeneic donor. Both Leu $2^{+}$and Leu $3^{+}$ subsets derived from CsA-treated cultures were suppressive of fresh MLR (Fig. $2 A$ ). This pattern was observed in 10 consecutive experiments that were performed with cells from unrelated individuals; this indicates that cells of both suppressor and inducer lineages participate in suppression. The possibility that suppression by alloactivated $\mathrm{T}$ cells of one phenotype was, in fact, mediated by contaminating cells of the reciprocal phenotype seems unlikely based upon the low level of contamination $(<3 \%)$ in positively selected preparations and the observation that suppression by Leu $2^{+}$and Leu $3^{+} \mathrm{T}$ cells were of similar potency and titer. Both cell types required activation, however, as indicated by the fact that $\mathrm{T}$ cells cultured alone for 12 $\mathrm{d}$ with or without CsA were nonsuppressive (Fig. $2 \mathrm{~A}$ ).

As shown in Fig. $2 \mathrm{~A}$, the Leu $8^{+}$subset of alloactivated $\mathbf{T}$ cells contained potent suppressor activity, whereas the Leu $8^{-}$subset had little activity. On the basis of these findings, alloactivated Leu $2^{+}$and Leu $3^{+}$cells were further subdivided into Leu $8^{+}$and Leu $8^{-}$subpopulations, and each subpopulation was tested functionally. As shown in Fig. $2 B$ and $C$, suppression by the Leu $3^{+}$subset was mediated exclusively by Leu $3^{+}, 8^{+}$cells; this finding was reproducible in four consecutive experiments. On the other hand, although the majority of suppression exerted by the Leu $2^{+}$subset was mediated by Leu $2^{+}, 8^{+}$cells, Leu $2^{+}, 8^{-}$were also
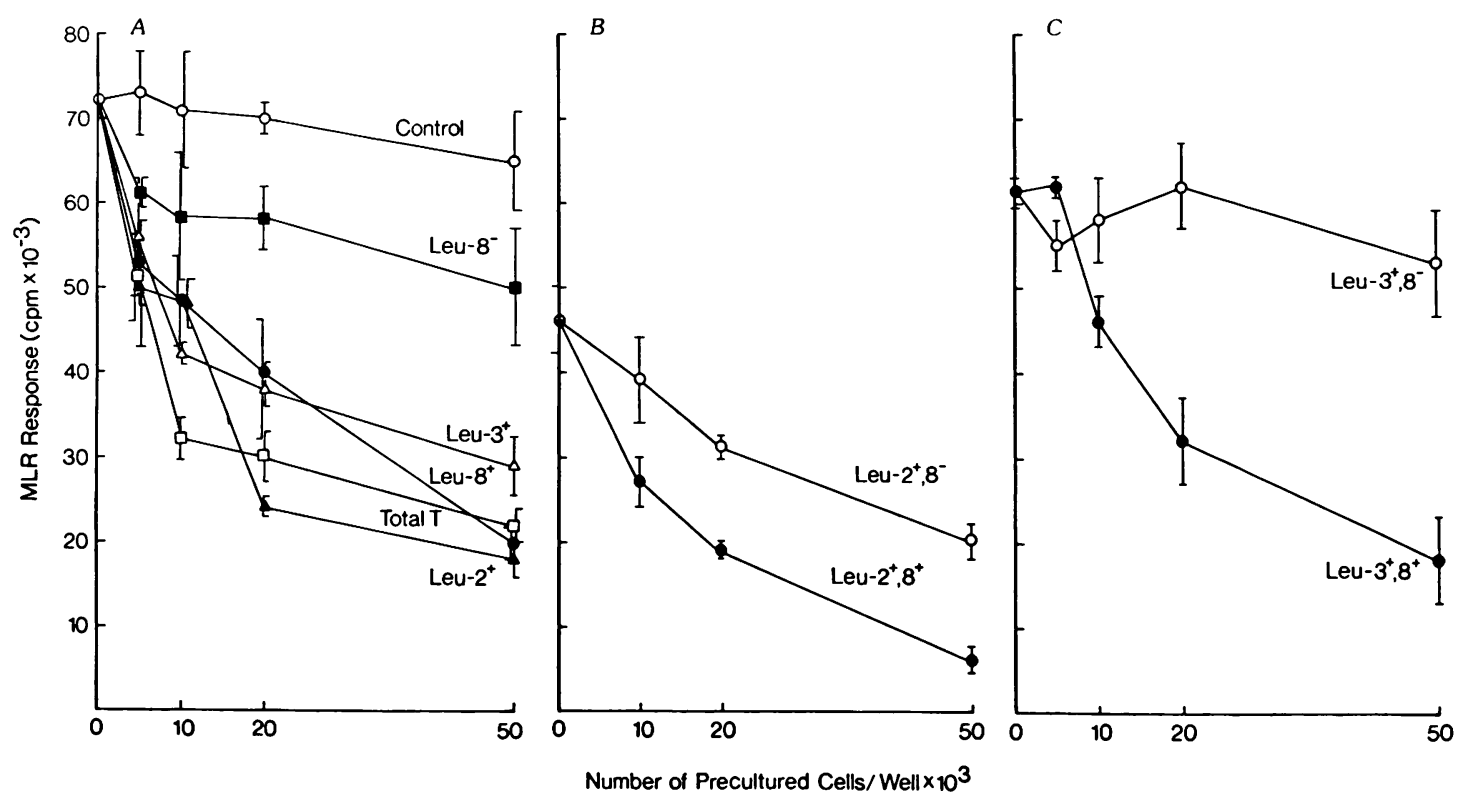

Figure 2 Regulation of MLR by T lymphocyte subsets derived from CsA-treated MLR. Unfractionated T cells were primed to allogeneic non-T cells in the presence of $1 \mu \mathrm{g} / \mathrm{ml} \mathrm{CsA}$. Thereafter, the activated cells were separated into subpopulations and tested for suppressive activity. In the experiments shown in $A$, graded numbers of irradiated $(1,500 \mathrm{R})$ unfractionated $T$ cells $(\bullet)$, and Leu $2^{+}(\Delta)$, Leu $3^{+}(\Delta)$, Leu $8^{+}(\square)$, and Leu $8^{-}(\square)$ cells were added to indicator MLR cultures which contained $10^{5}$ responder and stimulator cells. Proliferation was measured on day 6 and the results of sextuplicate cultures are presented as mean counts per minute $\pm S D$. Control MLR cultures $(O)$ contained fresh $T$ responder and non-T stimulator cells as well as irradiated (1,500 rad) $\mathrm{T}$ cells which had been incubated for $12 \mathrm{~d}$ in medium alone. In the results shown in $B$ and $C$, Leu $2^{+}$or Leu $3^{+}$cells derived from CsA-treated MLR were fractionated into Leu $8^{+}$and Leu $8^{-}$subsets, and graded numbers of irradiated $(1,500 \mathrm{rad})$ subpopulations were added to indicator MLR. 


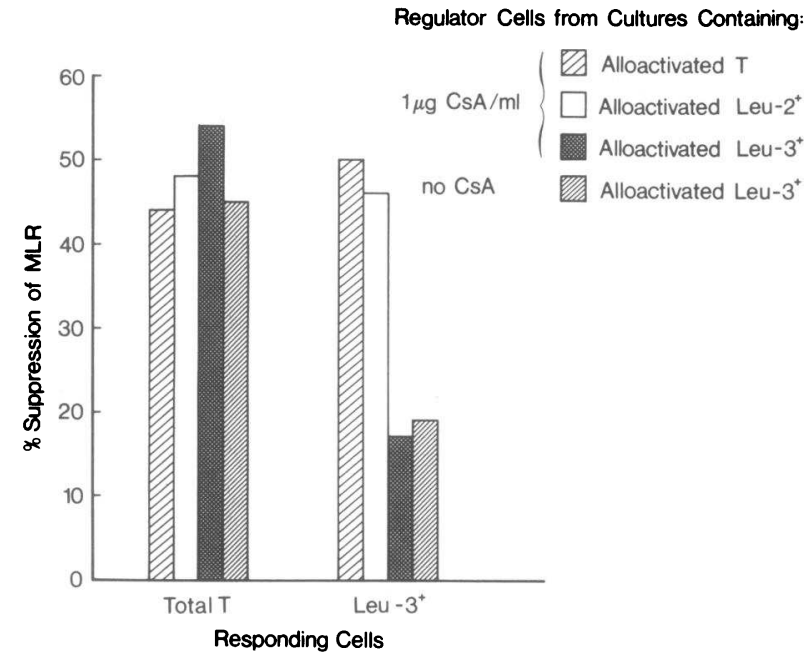

FIGURE 3 Induction of suppression by alloantigen-stimulated Leu $3^{+}$cells: MLR cultures were initiated in the absence or presence of CsA $(1 \mu \mathrm{g} / \mathrm{ml})$ as described in Methods. After $12 \mathrm{~d}, 2 \times 10^{4}$ unfractionated T cells, Leu $2^{+}$, or Leu $3^{+}$subsets were exposed to 1,500 rad and added to indicator MLR which contained either $10^{5}$ fresh T cells or Leu $3^{+}$cells as responders and $10^{5}$ irradiated allogeneic non-T cells. Proliferation was measured on day 6 and percent suppression of the MLR response was calculated for each group of six replicate cultures.

suppressive. Thus, some but not all cells within the two major $\mathrm{T}$ cell lineages appear to participate in suppression of the MLR.

The above results might be interpreted as indicating that both alloactivated Leu $2^{+}$and Leu $3^{+} \mathrm{T}$ cells can mediate suppression directly. Alternatively, one or both activated subsets may induce fresh $\mathrm{T}$ cells which are contained in the indicator MLR to become suppressoreffector cells. To test these possibilities, Leu $2^{+}$or Leu $3^{+}$cells recovered from CsA-treated MLR were cocultured in indicator MLR which contained either autologous unfractionated $\mathrm{T}$ or purified Leu $3^{+}$cells as responders. As shown in Fig. 3, alloactivated Leu $3^{+}$ cells induced potent suppression only in indicator MLR which contained fresh Leu $2^{+}$cells; they had little effect on MLR which contained only Leu $3^{+} \mathrm{T}$ cells as responders. Results from 10 consecutive experiments produced patterns similar to that depicted in Fig. 3; this suggests that, upon activation with alloantigen, Leu $3^{+}$cells acquire the capacity to induce fresh autologous Leu $2^{+}$cells to differentiate into functional suppressor-effector cells. Generation of Leu $3^{+}$suppressor-inducer cells does not require the presence of CsA, as alloactivated Leu $3^{+}$cells recovered from MLR devoid of CsA also induced suppressive activity in the fresh Leu $2^{+}$subset (Fig. 3). By contrast, Leu $2^{+}$cells derived from CsA-treated MLR suppressed the response of Leu $3^{+}$cells in the absence of fresh Leu $2^{+}$cells (Fig. 3). Leu $2^{+}$cells cultured with allogeneic non-T cells and CsA in the absence of Leu $3^{+}$cells failed to become suppressive (Table III); this indicated that the generation of Leu $2^{+}$suppressor cells requires the presence of alloactivated Leu $3^{+}$cells.

Although earlier experiments (Fig. 2) indicated that alloactivated Leu $3^{+}, 8^{+}$but not Leu $3^{+}, 8^{-}$cells were capable of inducing Leu $2^{+}$Ts, Leu $3^{+}, 8^{-}$cells may have played an essential role in the activation of Leu $3^{+}, 8^{+}$suppressor-inducer cells, or conceivably, Leu $3^{+}, 8^{+}$suppressor-inducer cells might have derived from Leu $3^{+}, 8^{-} \mathrm{T}$ cells that acquired the Leu 8 marker during culture. To examine these possibilities, Leu $3^{+}, 8^{+}$or Leu $3^{+}, 8^{-}$cells were isolated before stimulation with

TABLE III

Cellular Requirements for the Generation of Leu $2^{+}$Suppressor-effector Cells

\begin{tabular}{|c|c|c|c|c|}
\hline \multirow{3}{*}{ Cells in CsA culture } & \multicolumn{4}{|c|}{ Suppressor:responder cells } \\
\hline & \multicolumn{2}{|c|}{ 1:5 } & \multicolumn{2}{|c|}{$1: 20$} \\
\hline & $c p m \pm S D$ & $\%$ supp & $c p m \pm S D$ & $\%$ supp \\
\hline Leu $2^{+}$ & $16,988 \pm 1,812$ & 14 & $18,831 \pm 2,905$ & 5 \\
\hline $\begin{array}{l}\text { Leu } 2^{+} \\
\text {Allogeneic non-T }\end{array}$ & $14,608 \pm 2,606$ & 24 & $15,580 \pm 2,877$ & 21 \\
\hline $\begin{array}{l}\text { Leu } 2^{+} \\
\text {Allogeneic non-T } \\
\text { Autologous Leu } 3^{+}\end{array}$ & $5,529 \pm 885$ & 72 & $11,813 \pm 1,530$ & 40 \\
\hline
\end{tabular}

Leu $2^{+}$cells were cultured with and without stimulator or autologous Leu $3^{+}$cells for 12 $\mathrm{d}$ with $1 \mu \mathrm{g} / \mathrm{ml} \mathrm{CsA}$. Thereafter, Leu $2^{+}$cells were reisolated, irradiated $(1,500 \mathrm{rad})$ and co-cultured with $5 \times 10^{4}$ fresh autologous $\mathrm{T}$ cells and an equal number of irradiated $(3,000$ rad) allogeneic non-T cells. Proliferation was measured on day 6 and percent suppression of the MLR response was calculated for each group of four replicate cultures. MLR cultures containing no regulator cell averaged $19,730 \pm 2,905 \mathrm{cpm}$. \% supp, percent suppression. 
TABLE IV

Induction of Suppressor Cells by Leu $3^{+}, 8^{+}$and Leu $3^{+}, 8^{-}$Cells Separated prior to Activation

\begin{tabular}{|c|c|c|c|c|}
\hline \multirow{3}{*}{$\begin{array}{l}\text { Suppressor-inducer } \\
\text { cells }\end{array}$} & \multicolumn{4}{|c|}{ Suppressor:responder cells } \\
\hline & \multicolumn{2}{|c|}{$1: 5$} & \multicolumn{2}{|c|}{$1: 20$} \\
\hline & $c p m \pm S D$ & $\%$ supp & $c p m \pm S D$ & $\%$ supp \\
\hline T cell control & $26,138 \pm 612$ & 5 & $30,413 \pm 4,815$ & 0 \\
\hline Leu $3^{+}, 8^{-}$cells & $25,574 \pm 1,422$ & 7 & $36,168 \pm 3,410$ & 0 \\
\hline Leu $3^{+}, 8^{+}$cells & $5,809 \pm 1,819$ & 79 & $16,934 \pm 3,029$ & 39 \\
\hline
\end{tabular}

Fresh Leu $3^{+}, 8^{-}$or Leu $3^{+}, 8^{+}$cells were cultured for $12 \mathrm{~d}$ with $1 \mu \mathrm{g} / \mathrm{ml} \mathrm{CsA}$, autologous Leu $2^{+}$cells, and allogeneic non-T cells. Thereafter, Leu $3^{+}, 8^{-}$or Leu $3^{+}, 8^{+}$cells were reisolated irradiated (1,500 rad) and co-cultured with $5 \times 10^{4}$ fresh autologous $\mathrm{T}$ cells and an equal number of irradiated (3,000 rad) allogeneic non-T cells. Proliferation was measured on day 6 and percent suppression of the MLR response was calculated for each group of four replicate cultures. Irradiated (1,500 rad) non-activated T cells kept in medium containing $1 \mu \mathrm{g} / \mathrm{ml} \mathrm{CsA}$ for $12 \mathrm{~d}$ were added to the T cell control cultures. MLR cultures containing no regulator cell averaged $27,621 \pm 2,114 \mathrm{cpm}$. \% supp, percent suppression.

irradiated allogeneic non-T cells in the presence of CsA. $12 \mathrm{~d}$ later, the Leu $3^{+}$cells were reisolated, irradiated (1,500 rad), and co-cultured in indicator MLR which contained autologous unfractionated $\mathrm{T}$ cells as responders. As shown in Table IV, Leu $3^{+}, 8^{+}$cells alloactivated in the absence of Leu $3^{+}, 8^{-}$cells induced

TABLE V

Regulation of MLR by Leu $2^{+}, 8^{+}$and Leu $2^{+}, 8^{-}$Cells Separated prior to Activation

\begin{tabular}{llllll}
\hline & \multicolumn{5}{c}{ Suppressor:responder cells } \\
\cline { 2 - 6 } Suppressor cells & & & & $1: 10$ \\
\hline & $1: 5$ & & cpm $\pm S D$ & $\%$ supp
\end{tabular}

Experiment 1

\begin{tabular}{lrrrr} 
None & $103,995 \pm 8,971$ & & & \\
Leu $2^{+}$control & $102,271 \pm 9,738$ & 1 & ND $^{\bullet}$ & \\
Leu 2 & $55,843 \pm 6,806$ & 46 & $58,477 \pm 654$ & 44 \\
Leu $2^{+}, 8^{-}$ & $62,819 \pm 8,633$ & 40 & $76,725 \pm 6,689$ & 26 \\
Leu $2^{+}, 8^{+}$ & $57,844 \pm 1,916$ & 44 & $65,764 \pm 2,597$ & 37 \\
Experiment 2 & & & & \\
None & & & & \\
Leu 2 & & & & \\
Leu $2^{+}$ & $80,201 \pm 6,256$ & & & \\
Leu $2^{+}, 8^{-}$ & $86,201 \pm 7,465$ & 0 & $64,019 \pm 7,478$ & 21 \\
Leu $2^{+}, 8^{+}$ & $51,971 \pm 2,218$ & 37 & $67,055 \pm 5,251$ & 17 \\
\hline
\end{tabular}

Fresh Leu $2^{+}$cells as well as Leu $2^{+}, 8^{-}$or Leu $2^{+}, 8^{+}$subsets were primed with allogeneic non-T cells in the presence of autologous Leu $3^{+}$cells (Leu $2^{+}$:Leu $3^{+}$of $1: 2$ ) in cultures containing $1 \mu \mathrm{g} / \mathrm{ml} \mathrm{CsA}$. Thereafter, the activated Leu $2^{+}$cells were reisolated and tested for their suppressor activity. Graded numbers of irradiated (1,500 rad) regulator cells were co-cultured with $10^{5}$ fresh autologous $T$ cells and an equal number of irradiated allogeneic non-T cells. Proliferation was measured on day 6 and percent suppression of the MLR response was calculated for each group of four replicate cultures. Irradiated (1,500 rad) nonactivated T cells kept in medium containing $1 \mu \mathrm{g} / \mathrm{ml} \mathrm{CsA}$ for $12 \mathrm{~d}$ were added to the $\mathrm{T}$ cell control cultures. \% supp, percent suppression.

- ND, not done. 
potent suppression of the indicator MLR, whereas Leu $3^{+}, 8^{-}$cells primed to alloantigen in the absence of Leu $3^{+}, 8^{+}$cells failed to induce suppression. Thus, the isolated Leu $3^{+}, 8^{-}$subset does not contribute to the induction of suppression.

Similar experiments were carried out to identify precursors of Leu $2^{+}$suppressor cells. Fresh Leu $2^{+}, 8^{+}$or Leu $2^{+}, 8^{-}$cells were cultured with autologous Leu $3^{+}$ cells and allogeneic non-T stimulators in the presence of CsA, and were then reisolated and tested for the ability to inhibit indicator MLR. The results summarized in Table $\mathrm{V}$ show that both Leu $2^{+}, 8^{+}$and Leu $2^{+}, 8^{-}$subsets are capable of becoming $\mathrm{Ts}$, and these Ts are of similar potency and titer. Additional experiments indicated that the Leu 8 marker remained on Leu $8^{+}$cells and did not appear on Leu $8^{-}$cells throughout the culture period; this indicated that the presence or absence of this marker is a stable phenotypic trait under the conditions described (data not shown).

To determine whether the cellular target of Ts derived from CsA-treated MLR is confined to either one of the Leu $3^{+}$subpopulations defined with anti-Leu 8 antibody, fresh Leu $3^{+}$cells were divided into Leu $3^{+}, 8^{-}$and Leu $3^{+}, 8^{+}$fractions by panning before being used as responders as indicator MLR. As shown in Table VI, alloactivated T cells derived from CsA-treated MLR suppressed equally the response of both Leu $3^{+}, 8^{-}$and Leu $3^{+}, 8^{+}$subsets.

\section{DISCUSSION}

These results confirm that potent, alloantigen-specific Leu $2^{+}$Ts can be generated in vitro in the absence of classical Tc (9). In addition, they show that the acti- vation of Ts is dependent on a subpopulation of inducer $T$ cells that bear the Leu $3^{+}, 8^{+}$phenotype. To become suppressor-inducer cells, Leu $3^{+}, 8^{+}$cells required culture with allogeneic non-T cells but not Leu $3^{+}, 8^{-}$cells, which played no detectable role in this suppressor system. The resistance of alloactivated Leu $3^{+}, 8^{+}$cells to 1,500 rad suggests that, once primed to alloantigen, these cells do not need to proliferate in order to activate suppressor cells. Analogous interactions between T cells of helper and suppressor/cytotoxic lineage are required for the generation of Tc (4) as well as Ts of humoral immunity (19), although, as discussed below, the Leu $3^{+}$inducers of Ts and Tc may not be identical to one another. At the very least, the observation that Leu $3^{+}, 8^{+}$but not Leu $3^{+}, 8^{-}$cells activate alloantigen-specific Ts suggests that individual Leu $3^{+}$cells have limited functional repertoires.

The suppressor-effectors in this system are confined to the Leu $2^{+}$subset. Unlike the inducer subset, the Leu 8 marker did not distinguish clearly between Leu $2^{+}$cells that do or do not participate in suppression, as both activated Leu $2^{+}, 8^{+}$and Leu $2^{+}, 8^{-}$cells inhibited indicator MLR. It is possible that both of these subpopulations include suppressor-effector cells that directly inhibit proliferation in MLR. The data do not rule out the possibility that one or both of these populations may also include cells that amplify the suppressive effects of fresh $T$ cells present in the indicator MLR in a manner similar to that described for the regulation of immunoglobulin synthesis induced in MLR (14). Regardless of the precise mechanism whereby Leu $2^{+}$cells inhibit the MLR, the results in Table VI show that both Leu $3^{+}, 8^{+}$and Leu $3^{+}, 8^{-}$

TABLE VI

Cellular Target of Suppressor T Cells Derived From CsA-Treated MLR

\begin{tabular}{|c|c|c|c|c|c|}
\hline \multirow{3}{*}{$\begin{array}{l}\text { Responder cells in } \\
\text { indicator MLR }\end{array}$} & \multirow{3}{*}{$\begin{array}{c}\text { No suppressor } \\
\text { cpm } \pm S D\end{array}$} & \multicolumn{4}{|c|}{ Suppressor:responder cells } \\
\hline & & \multicolumn{2}{|c|}{$1: 5$} & \multicolumn{2}{|c|}{$1: 20$} \\
\hline & & $c p m \pm S D$ & $\% \operatorname{supp}$ & $c p m \pm S D$ & $\%$ supp \\
\hline \multicolumn{6}{|l|}{ Experiment 1} \\
\hline Total T & $82,849 \pm 2,607$ & $42,953 \pm 2,550$ & 48 & $75,644 \pm 5,543$ & 9 \\
\hline Leu $3^{+}, 8^{-}$ & $98,202 \pm 11,643$ & $30,087 \pm 8,014$ & 69 & $63,900 \pm 1,614$ & 35 \\
\hline Leu $3^{+}, 8^{+}$ & $96,745 \pm 10,378$ & $40,767 \pm 5,247$ & 58 & $62,973 \pm 2,894$ & 35 \\
\hline \multicolumn{6}{|l|}{ Experiment 2} \\
\hline Total T & $\mathrm{ND}^{\bullet}$ & ND• & & $\mathrm{ND}^{\bullet}$ & \\
\hline Leu $3^{+}, 8^{-}$ & $103,995 \pm 897$ & $27,871 \pm 6,546$ & 73 & $74,831 \pm 6,162$ & 28 \\
\hline Leu $3^{+}, 8^{+}$ & $96,942 \pm 3,878$ & $38,870 \pm 4,763$ & 60 & $81,697 \pm 8,649$ & 16 \\
\hline
\end{tabular}

T cells activated in CsA-treated MLR were tested for their ability to suppress the proliferative response of $10^{5}$ fresh autologous total $T$, Leu $3^{+}, 8^{-}$, or Leu $3^{+}, 8^{+}$cells to an equal number of irradiated allogeneic non- $T$ cells. Proliferation was measured on day 6 and percent suppression of the MLR response was calculated for each group of four replicate cultures. \% supp, percent suppression.

- ND, not done. 
subsets are targets of suppression. This observation, when combined with the knowledge that the Leu $3^{+}$ cells that proliferate in MLR induce the differentiation of cytotoxic T cells and Ig-secreting B cells as well as suppressor $\mathrm{T}$ cells, suggests that activated Leu $2^{+} \mathrm{Ts}$ inhibit diverse functions. These possibilities await direct confirmation.

Once activated, Ts only inhibited the response of fresh $T$ cells to the priming cell or cells that share at least one HLA-DR allele with the priming cell. It is possible that products of genes linked to HLA-DR rather than DR antigens themselves are the stimuli of Ts. However, the results appear to exclude a role for Class I major histocompatibility complex (MHC) antigens (HLA-A and B), based on the repeated observation that activated Ts inhibited the response to stimulators that shared DR alleles with the priming cell regardless of their HLA-A and B type. In one experiment (see Table II), activated Ts strongly inhibited the response to Daudi cells, which express no HLA-A or B antigens but shared the DR6 allele with the priming cell. In earlier studies, Hess and Tutschka (9) observed that MLR carried out in the presence of CsA resulted in both stimulator cellspecific and nonspecific Ts, although, at doses of CsA that blocked proliferation $(1.25 \mu \mathrm{g} / \mathrm{ml}$ or greater $)$, specific suppression was favored. We and others have previously reported the development of specific and nonspecific Ts in MLR that were carried out in the absence of CsA $(2,3)$. In our experience, alloactivated T cells, if not irradiated (1,000-1,500 rad) or treated with mitomycin $\mathrm{C}$, can exert potent nonspecific suppression probably related to their proliferation and resultant absorption or utilization of essential growth factors (3). On the basis of this experience, all of the experiments described here utilized Ts that were irradiated after their activation in primary cultures, and only stimulator cell-specific suppression was observed.

The apparent specificity of alloactivated Ts for Class II MHC determinants on allogeneic stimulator cells might appear to contradict our previous suggestion that Leu $3^{+}$but not Leu $2^{+}$cells are triggered by Class II MHC antigens (13). However, earlier studies were confined to the induction of proliferation (13), help (8, 19 ), and cytolysis $(6,7)$. Furthermore, as shown in Fig. 1 , suppression by alloactivated Ts was not affected by increasing the number of stimulator non- $T$ cells in the indicator MLR; this suggests that such cells are not the target of suppression. In this regard, recent studies indicate that structures on or secreted by alloantigenprimed Leu $3^{+}$cells trigger Leu $2^{+}$T cells to become suppressors and these Ts, in turn, act at the level of Leu $3^{+}$responder cells rather than stimulator non-T cells (20). Therefore, despite the specificity of suppressor T cells for HLA-DR, neither the generation nor effector phase of suppression necessarily involves direct interaction of Ts cells with Class II MHC determinants.

Finally, it is interesting to consider these results in the context of published studies of the effects of CsA on the immune response. Several investigators have shown that this agent blocks the activation of helper/ inducer $\mathrm{T}$ cells which are required for generation of Tc, but does not affect lysis of target cells by mature Tc (21-25). This has led to the suggestion that the primary cellular target of CsA is an inducer $\mathrm{T}$ cell. On the other hand, the observations that CsA prevents Tc precursors from responding to $\mathrm{T}$ cell growth factors $(23,26,27)$ and blocks proliferation of both alloreactive cytolytic and helper $T$ cell clones (27) have led to the suggestion that CsA affects all alloantigen-sensitized $\mathrm{T}$ cells (27). The finding in the current study that suppressor-inducer cells are activated in the presence of CsA argues for a modification of this hypothesis and suggests that suppressor-inducer and $\mathrm{Tc}$-inducer functions of Leu $3^{+} \mathrm{T}$ cells are differentially sensitive to CsA. Indeed, the fact that Leu $3^{+}, 8^{+}$cells provide most of the Ts-inducer activity in the MLR, whereas Leu $3^{+}, 8^{-}$cells provide the majority of helper-inducer activity in assays of B cell differentiation (14) suggests that these two functions are mediated by distinct subpopulations of Leu $3^{+}$cells; this is a proposal that has been made by others as well (27).

\section{ACKNOWLEDGMENTS}

This work was supported by National Institutes of Health grants HL13108, AM32075, and CA24607.

\section{REFERENCES}

1. Bach, F. H., M. L. Bach, and P. M. Sondel. 1976. Differential function of major histocompatibility complex antigens in T-lymphocyte activation. Nature (Lond.). 259:273-281

2. Sheehy, M. J., C. Mawas, and D. J. Charmot. 1979. Specific inhibition of human lymphocyte responses by primed autologous lymphocytes. I. Evaluation of MLR inhibition as a model for suppression. J. Immunol. 122:2198-2203.

3. Engleman, E. G., C. J. Benike, and D. J. Charron. 1980. Ia antigen on peripheral blood mononuclear leukocytes in man. II. Functional studies of HLA-DR positive T cells activated in mixed lymphocyte reactions. J. Exp. Med. 152:114-126.

4. Evans, R. L., H. Lazarus, A. C. Penta, and S. F. Schlossman. 1978. Two functionally distinct subpopulations of human $\mathrm{T}$ cells that collaborate in the generation of cytotoxic cells responsible for cell-mediated lympholysis. J. Immunol. 120:1423-1428.

5. Reinherz, E. L., P. C. Kung, G. Goldstein, and S. F. Schlossman. 1979. Separation of functional subsets of human $\mathrm{T}$ cells by a monoclonal antibody. Proc. Natl. Acad. Sci. USA. 76:4061-4065.

6. Reinherz, E. L., P. C. Kung, G. Goldstein, and S. F. Schlossman. 1980. A monoclonal antibody reactive with 
the human cytotoxic/suppressor $\mathrm{T}$ cell subset previously defined by a heteroantisera termed $\mathrm{TH}_{2}$. J. Immunol. 124:1301-1307.

7. Evans, R. L., D. W. Wall, C. D. Platsoucas, F. P. Siegal, S. M. Fikrig, C. M. Testa, and R. A. Good. 1981. Thymusdependent membrane antigens in man: inhibition of cellmediated lympholysis by monoclonal antibodies to $\mathrm{TH}_{2}$ antigen. Proc. Natl. Acad. Sci. USA. 78:544-548.

8. Kotzin, B. L., C. J. Benike, and E. G. Engleman. 1981. Induction of immunoglobulin-secreting cells in the allogeneic mixed leukocyte reaction: regulation by helper and suppressor lymphocyte subsets in man. J. Immunol. 127:931-935.

9. Hess, A. D., and P. J. Tutschka. 1980. Effect of cyclosporin A on human lymphocyte responses in vitro. I. CsA allows for the expression of alloantigen-activated suppressor cells while preferentially inhibiting the induction of cytolytic effector lymphocytes in MLR. J. Immunol. 124:26012608.

10. Borel, J. F., C. Feurer, C. Magnee, and H. Stahelin. 1977. Effects of the new anti-lymphocyte peptide cyclosporin $\mathrm{A}$ in animals. Immunology. 32:1017-1025.

11. Green, C. L., and A. C. Allison. 1978. Extensive prolongation of rabbit kidney allograft survival after shortterm cyclosporin A treatment. Lancet. I:1182-1183.

12. Calne, R. Y., D. J. G. White, D. B. Evans, P. McMaster, D. C. Dunn, G. N. Craddock, B. D. Pentlow, and K. Rolles. 1878. Cyclosporin A in patients receiving renal allografts from cadaver donors. Lancet. II:1323-1327.

13. Engleman, E. G., C. J. Benike, F. C. Grumet, and R. L. Evans. 1981. Activation of human T lymphocyte subsets. Helper and suppressor/cytotoxic $T$ cells recognize and respond to distinct histocompatibility antigens. J. Immunol. 127:2124-2129.

14. Gatenby, P. A., G. S. Kansas, C. Y., Xian, R. L. Evans, and E. G. Engleman. 1982. Dissection of immunoregulatory subpopulations of $\mathrm{T}$ lymphocytes within the helper and suppressor sublineages in man. J. Immunol. 129:1997-2000.

15. Boyum, A. 1968. Isolation of mononuclear cells and granulocytes from human blood. Scand. J. Clin. Lab. Invest. 21(Suppl. 97):77.

16. Saxon, A., J. Feldhaus, and R. A. Robins. 1976. Single step separation of human T and B cells using AET treated sheep red cells. J. Immunol. Methods. 12:285-288.

17. Engleman, E. G., R. Warnke, R. I. Fox, J. Dilley, C. J.
Benike, and R. Levy. 1981. Studies of a human T lymphocyte antigen recognized by a monoclonal antibody. Proc. Natl. Acad. Sci. USA. 78:1791-1795.

18. Zarling, J. M., M. McKeough, and F. H. Bach. 1976. A sensitive micromethod for generating and assaying allogeneically induced cytotoxic human lymphocytes. Transplantation (Baltimore). 21:468-476.

19. Gatenby, P. A., B. L. Kotzin, and E. G. Engleman. 1981. Induction of immunoglobulin-secreting cells in the human autologous mixed leukocyte reaction: regulation by helper and suppressor lymphocyte subsets defined with monoclonal antibodies. J. Immunol. 127:2130-2135.

20. Damle, N. K., and E. G. Engleman. 1983. Immunoregulatory $\mathrm{T}$-cell circuits in man. Alloantigen-primed inducer $\mathrm{T}$ cells activate alloantigen-specific suppressor $\mathrm{T}$ cells in the absence of the initial antigenic stimulus. J. Exp. Med. 158:159-173

21. Hess, A. D., P. J. Tutschka, Z. Pu, and G. W. Santos. 1982. Effect of cyclosporin A on human lymphocyte responses in vitro. IV. Production of $T$ cell stimulatory growth factors and development of responsiveness to these growth factors in CsA-treated primary MLR cultures. $J$. Immunol. 128:360-367.

22. Palacios, R. 1981. Cyclosporin A inhibits the proliferative response and the generation of helper, suppressor and cytotoxic $\mathrm{T}$-cell functions in the autologous mixed lymphocyte reaction. Cell Immunol. 61:453-462.

23. Wang, B. S., E. H. Heacock, K. H. Collins, I. F. Hutchinson, N. L. Tilney, and J. A. Mannick. 1981. Suppression effects of cyclosporin $\mathrm{A}$ on the induction of alloreactivity in vitro and in vivo. J. Immunol. 127:89-93.

24. Larsson, E. L. 1980. Cyclosporin A and dexamethasone suppress $\mathrm{T}$ cell responses by selectively acting at distinct sites of the triggering process. J. Immunol. 124:28282833.

25. Palacios, R., and G. Moller. 1981. Cyclosporin A blocks receptors for HLA-DR antigens on $\mathrm{T}$ cells. Nature (Lond.). 290:792-794.

26. Orosz, C. G., R. K. Fidelus, D. C. Roopenian, M. B. Widmer, R. M. Ferguson, and F. H. Bach. 1982. Analysis of cloned $\mathrm{T}$ cell function $\mathrm{I}$. Dissection of cloned $\mathrm{T}$ cell proliferative responses using cyclosporin A. J. Immunol. 128:1865-1868

27. Morimoto, C., E. L. Reinherz, Y. Borel, and S. F. Schlossman. 1983. Direct demonstration of the human suppressor inducer subset by anti-T cell antibodies. J. Immunol. 130:157-161. 